\title{
Management of fourth degree obstetric perineal tear without colostomy using non - stimulated gracilis - our experience over eleven years
}

\author{
Jiten Kulkarni, Anuradha J. Patil, Bhaskar Musande, Abhishek B. Bhamare \\ Department of Plastic Surgery, MGM Medical College, Aurangabad, Maharashtra, India
}

Address for correspondence: Dr. Jiten Kulkarni, Nirmiti Hospital, 4, Ashok Nagar, Garkheda, Aurangabad - 431005, Maharashtra, India. E-mail: drjitenkulkarni@gmail.com

\section{ABSTRACT}

Background: Although gracilis muscle transposition for faecal incontinence has been well-described method, its literature for use in obstetric perineal tear without colostomy is sparse. In this study, we have tried to analyse its use in fourth-degree obstetric perineal tears. Patients and Methods: A total of 30 patients with recto-vaginal fistula with faecal incontinence secondary to obstetric perineal tear were retrospectively studied between February 2003 and May 2014. The recto-vaginal fistula was explored, dissected and identification of sphincters was done using muscle stimulator. Fistula closure was done followed by sphincter repair, vaginal tightening procedure and single gracilis transposition. None of the patients had covering colostomy. Faecal incontinence was assessed pre- and post-operatively by digital rectal examination (single examiner), Park's score and Corman's score in all cases and using barium hold and transperineal ultrasonography, manometric studies in a few cases. The outcome was measured at an average follow-up of 8.8 months (7-24 months). Results: As per Park's score 26 patients had Grade I continence, two had Grade II and two patients had Grade III continence. Corman's score improved from fair to excellent in 26 patients. The patients in whom manometry was performed showed a remarkable rise in both resting and squeeze pressures. Two patients developed post-operative infections in upper 1/3 thigh incision site and three patients at gluteal region scar site. Conclusion: Satisfactory continence following gracilis muscle could be achieved.

\section{KEY WORDS}

Anal incontinence; gracilis; obstetric perineal tear; recto-vaginal fistula

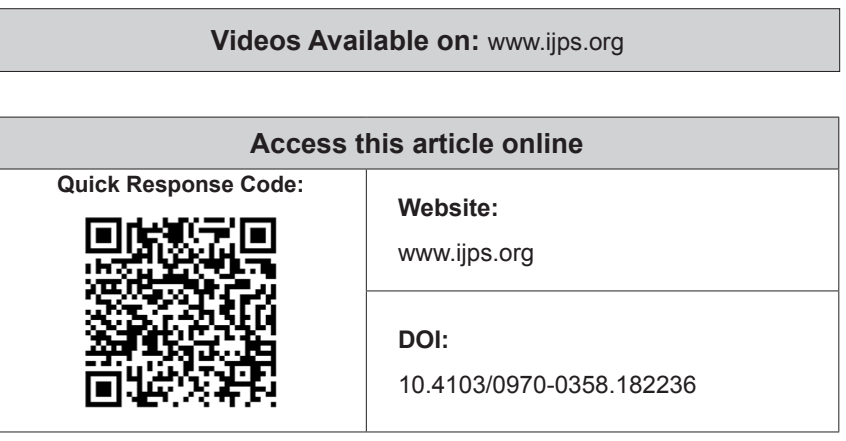

This is an open access article distributed under the terms of the Creative Commons Attribution-NonCommercial-ShareAlike 3.0 License, which allows others to remix, tweak, and build upon the work non-commercially, as long as the author is credited and the new creations are licensed under the identical terms.

For reprints contact: reprints@medknow.com

How to cite this article: Kulkarni J, Patil AJ, Musande B, Bhamare AB. Management of fourth degree obstetric perineal tear without colostomy using non - stimulated gracilis - our experience over eleven years. Indian J Plast Surg 2016;49:26-34. 


\section{INTRODUCTION}

econstruction of the anal sphincter was first described in 1946 by Pickrell et al., ${ }^{[1]}$ reporting their results in four children with faecal incontinence, with a follow-up study of further cases reported shortly thereafter. ${ }^{[2]}$ The subsequent literature, while useful in defining the surgical technique, is mostly concerned with faecal incontinence, which is not obstetric in origin. The first reference to the use of this technique in obstetric practice was not until $1979,,^{[3]}$ although a defect of the anal sphincter following vaginal delivery is the most common cause of faecal incontinence in women. ${ }^{[4]}$ The incidence of anal sphincter tears at delivery varies from $0.6 \%$ to $6 \%{ }^{[4,5]}$ with nearly $50 \%$ of women developing anal incontinence after primary repair. ${ }^{[4-8]}$ In one study, all patients with anal incontinence following primary repair had persistent anal sphincter defects. ${ }^{[4]}$ However, 35-41\% of all primipara had identifiable sphincter defects at follow-up investigation by endosonography, ${ }^{[8,9]}$ although most of these did not affect anal function..$^{[9]}$ Analysis of the long-term effects of anorectal function after third-degree obstetric tears as a result of obstetric injury suggested that anal function deteriorates further over time and with subsequent vaginal deliveries. ${ }^{[10]}$

Use of the gracilis muscle to correct obstetric perineal tears is reported to have good results. ${ }^{[1-20]}$

This study reports the results of treatment of faecal incontinence of obstetric origin by exploration of the recto-vaginal fistula, reconstitution of the posterior vaginal wall and the anterior wall of the ano-rectum, using a single non-stimulated gracilis reconstruction of the anal sphincter without colostomy in thirty female patients.

\section{PATIENTS AND METHODS}

Between February 2003 to May 2014, thirty female patients with an age range of 21-59 years (mean: 36.7) with complete posterior vaginal tears into the rectum and faecal incontinence as a result of obstetrical injury were treated by exploration of the recto-vaginal fistula, fistula closure, sphincter repair, vaginal tightening procedure and single gracilis reconstruction of the anal sphincter by gracilis transposition. The intention was to recreate the sphincters, separate the vaginal mucosa from the anal wall and provide soft tissue interposition using gracilis muscle. Patients had an average follow-up of 8.8 months (3-24 months). The patients underwent thorough preoperative counselling.

All the patients were assessed preoperatively by Park's score $^{[21]}$ and Corman's score [Table 1]. Digital rectal examination (DRE) was performed by the author pre- and post-operatively in all the patients. The patients were examined in left lateral and lithotomy position [Figure-1]. Anal sphincter tone was assessed at rest, on squeeze and on thigh adduction ${ }^{[22]}$ [Table 2].

Transperineal ultrasonography and barium enema was done pre-operatively in all patients. Transperineal ultrasound was performed to demonstrate the anal sphincter thickness ${ }^{[10]}$ [Table 3]. Barium enema was done using a thin paste of $50 \%$ barium prepared in $300 \mathrm{ml}$ normal saline. The patient was advised rotatory movements in supine position on table and walking for 20-30 m. Lateral and supine films were taken with a

Table 1: Pre- and post-operative scores

\begin{tabular}{|c|c|c|c|c|}
\hline $\begin{array}{l}\text { Case } \\
\text { number }\end{array}$ & $\begin{array}{l}\text { Pre- } \\
\text { operative } \\
\text { Corman score }\end{array}$ & $\begin{array}{l}\text { Post- } \\
\text { operative } \\
\text { Corman score }\end{array}$ & $\begin{array}{c}\text { Pre- } \\
\text { operative } \\
\text { Parks score }\end{array}$ & $\begin{array}{c}\text { Post- } \\
\text { operative } \\
\text { Parks score }\end{array}$ \\
\hline 1 & Fair & Excellent & 3 & 1 \\
\hline 2 & Poor & Good & 4 & 2 \\
\hline 3 & Poor & Excellent & 4 & 1 \\
\hline 4 & Fair & Excellent & 3 & 1 \\
\hline 5 & Fair & Excellent & 3 & 1 \\
\hline 6 & Fair & Excellent & 3 & 1 \\
\hline 7 & Fair & Excellent & 3 & 1 \\
\hline 8 & Fair & Excellent & 3 & 1 \\
\hline 9 & Fair & Excellent & 3 & 1 \\
\hline 10 & Fair & Excellent & 3 & 1 \\
\hline 11 & Fair & Excellent & 3 & 1 \\
\hline 12 & Fair & Excellent & 3 & 1 \\
\hline 13 & Fair & Good & 3 & 2 \\
\hline 14 & Fair & Excellent & 3 & 1 \\
\hline 15 & Fair & Fair & 3 & 3 \\
\hline 16 & Fair & Excellent & 3 & 1 \\
\hline 17 & Poor & Excellent & 4 & 1 \\
\hline 18 & Fair & Excellent & 3 & 1 \\
\hline 19 & Fair & Excellent & 3 & 1 \\
\hline 20 & Fair & Excellent & 3 & 1 \\
\hline 21 & Fair & Fair & 3 & 3 \\
\hline 22 & Fair & Excellent & 4 & 1 \\
\hline 23 & Fair & Excellent & 4 & 1 \\
\hline 24 & Fair & Excellent & 3 & 1 \\
\hline 25 & Poor & Excellent & 3 & 1 \\
\hline 26 & Poor & Excellent & 4 & 1 \\
\hline 27 & Poor & Excellent & 4 & 1 \\
\hline 28 & Poor & Excellent & 4 & 1 \\
\hline 29 & Poor & Excellent & 4 & 1 \\
\hline 30 & Poor & Excellent & 4 & 1 \\
\hline
\end{tabular}


Table 2: Anal sphincter tone assessment with DRE

\begin{tabular}{|c|c|c|c|c|c|c|c|}
\hline CASE NO & Age yrs & Post delivery yrs & $\begin{array}{l}\text { Pre-op PR } \\
\text { exam at rest }\end{array}$ & on Squeeze & $\begin{array}{l}\text { Postop PR } \\
\text { exam at rest }\end{array}$ & on Squeeze & on Adduction of thigh \\
\hline 1 & 28 & 4 & Lax & No gripping & Normal & Gripping & Constricting feel \\
\hline 2 & 29 & 5 & Lax & No gripping & Weak & Weak & Weak \\
\hline 3 & 58 & 35 & Lax & No gripping & Normal & Gripping & Constricting feel \\
\hline 4 & 36 & 16 & Lax & No gripping & Normal & Gripping & Constricting feel \\
\hline 5 & 38 & 12 & Lax & No gripping & Weak & Weak & Weak Constricting feel \\
\hline 6 & 46 & 13 & Lax & No gripping & Normal & Gripping & Constricting feel \\
\hline 7 & 35 & 12 & Lax & No gripping & Normal & Gripping & Constricting feel \\
\hline 8 & 47 & 15 & Lax & No gripping & Normal & Gripping & Constricting feel \\
\hline 9 & 34 & 12 & Lax & No gripping & Normal & Gripping & Constricting feel \\
\hline 10 & 26 & 7 & Lax & No gripping & Normal & Gripping & Constricting feel \\
\hline 11 & 34 & 7 & Lax & No gripping & Normal & Gripping & Constricting feel \\
\hline 12 & 21 & 1.5 & Lax & No gripping & Normal & Gripping & Constricting feel \\
\hline 13 & 33 & 8 & Lax & No gripping & Weak & Weak & Weak \\
\hline 14 & 34 & 12 & Lax & No gripping & Normal & Gripping & Constricting feel \\
\hline 15 & 59 & 34 & Lax & No gripping & Weak & Weak & Weak \\
\hline 16 & 35 & 12 & Lax & No gripping & Normal & Gripping & Constricting feel \\
\hline 17 & 24 & 4 & & No gripping & Normal & Gripping & Constricting feel \\
\hline 18 & 30 & 4 & Lax & No gripping & Normal & Gripping & Constricting feel \\
\hline 19 & 41 & 13 & Lax & No gripping & Weak & Weak & Constricting feel \\
\hline 20 & 45 & 14 & Lax & No gripping & Normal & Gripping & Constricting feel \\
\hline 21 & 38 & 13 & Lax & No gripping & Weak & Weak & Weak \\
\hline 22 & 40 & 19 & Lax & No gripping & Weak & Weak & Constricting feel \\
\hline 23 & 49 & 24 & Lax & No gripping & Normal & Gripping & Constricting feel \\
\hline 24 & 36 & 14 & Lax & No gripping & Normal & Gripping & Constricting feel \\
\hline 25 & 47 & 30 & Lax & No gripping & Weak & Weak & Constricting feel \\
\hline 26 & 25 & 8 & Lax & No gripping & Normal & Gripping & Constricting feel \\
\hline 27 & 36 & 4 & Lax & No gripping & Normal & Gripping & Constricting feel \\
\hline 28 & 36 & 5 & Lax & No gripping & Weak & Weak & Constricting feel \\
\hline 29 & 34 & 4 & Lax & No gripping & Normal & Gripping & Constricting feel \\
\hline 30 & 28 & 5 & Lax & No gripping & Normal & Gripping & Constricting feel \\
\hline
\end{tabular}

marker at anal verge ${ }^{[18]}[$ Table 4]. Barium holding time was noted in the patients.

Six patients underwent rectal manometry to assess resting and squeeze pressures [Table 5].

\section{Surgical technique}

Bowel preparation was done the day before the surgery. Under combined spinal and epidural anaesthesia, with a urinary catheter in situ, the patient was placed in the exaggerated lithotomy position with head low. A line joining the adductor tightness/tubercle and the midpoint of the knee joint line was marked. Two fingerbreadths below and parallel to the above line three incisions were marked. The fourth incision was marked on the upper third leg encircling the tibial tuberosity [Figure 2]. After infiltration, single gracilis was harvested along its length to include $1-2 \mathrm{~cm}$ of adjoining tibial periosteum beyond the insertion [Figure 3]. The harvested gracilis was tunnelled into the perineum through a subcutaneous tunnel, the pivot point being the pedicle with a $\mathrm{cm}$ of fat around it.
Double opposing skin flaps were marked at the junction of vaginal and anal mucosae [Figure 4].

Meticulous dissection was performed to separate the anorectal and vaginal mucosae, keeping close to the latter. Once the dissection reached the virgin tissue above the recto-vaginal tear, blunt finger separation of the vagina and rectum was carried out up to 8-9 $\mathrm{cm}$, to the full length of the operator's index finger [Figure 5 and Video 1]. Two horizontal curvilinear incisions were marked on the buttocks $1.5-2.0 \mathrm{~cm}$ posterior to the anus and overlying the ischial tuberosities. Tunnels were made superior to the ano-coccygeal raphe by blunt finger dissection from these incisions. Tunnels were also made on either side of anal canal [Video 2]. The posterior vaginal mucosa was trimmed judiciously [Figure 6]. The anal fistula was then repaired with interrupted $3 / 0$ Vicryl sutures. The anorectal sphincter tissue was identified and confirmed by use of a muscle stimulator on either side of the tear and repaired end to end using interrupted $2 / 0$ Vicryl. The gracilis muscle was then passed twice 
Table 3: Transperineal ultrasonography for thickness in $\mathrm{mm}$ with follow-up in months

\begin{tabular}{|c|c|c|c|}
\hline $\begin{array}{l}\text { Case } \\
\text { number }\end{array}$ & $\begin{array}{c}\text { Transperineal USG } \\
\text { pre-operative }\end{array}$ & $\begin{array}{l}\text { Transperineal USG } \\
\text { post-operative }\end{array}$ & $\begin{array}{l}\text { Follow-up } \\
\text { in months }\end{array}$ \\
\hline 1 & 3 & 8 & 18 \\
\hline 2 & 2.6 & Not done & 8 \\
\hline 3 & 3 & Not done & 6 \\
\hline 4 & 2.4 & Not done & 7 \\
\hline 5 & 3.2 & Not done & 7 \\
\hline 6 & 2.8 & Not done & 6 \\
\hline 7 & 2.2 & 10 & 24 \\
\hline 8 & 3.2 & Not done & 12 \\
\hline 9 & 2 & Not done & 6 \\
\hline 10 & 2.8 & Not done & 6 \\
\hline 11 & 3.2 & Not done & 6 \\
\hline 12 & 2.4 & Not done & 4 \\
\hline 13 & 2 & 4 & 8 \\
\hline 14 & 2.6 & Not done & 9 \\
\hline 15 & 2.2 & Not done & 7 \\
\hline 16 & 2.9 & 9 & 10 \\
\hline 17 & 2.7 & 8 & 7 \\
\hline 18 & 3 & 11 & 24 \\
\hline 19 & 2.4 & 6 & 14 \\
\hline 20 & 2.6 & 8 & 9 \\
\hline 21 & 2.2 & Not done & 7 \\
\hline 22 & 2 & Not done & 12 \\
\hline 23 & 1.3 & 8 & 6 \\
\hline 24 & 2 & 8 & 6 \\
\hline 25 & 2.4 & 6 & 6 \\
\hline 26 & 2.6 & Not done & 6 \\
\hline 27 & 3.2 & Not done & 3 \\
\hline 28 & 2.4 & Not done & 6 \\
\hline 29 & 2.2 & Not done & 6 \\
\hline 30 & 2.6 & Not done & 6 \\
\hline
\end{tabular}

in a clockwise direction so that bulk of the muscle was between the critical areas of fistula. A periosteal stitch with no.1 prolene was taken through ischial tuberosity under direct vision using an illuminated retractor. This prolene stitch was taken through the contralateral ischial tuberosity in 26 patients. The donor's thigh was taken out from lithotomy position and held in adduction. The prolene suture of ischial periosteal stitch was weaved through the gracilis tendon and tension adjustment was done, in adduction by assessing the anal tone [Figure 7 and Video 3].

None of the patients in this series were subjected to the colostomy.

\section{Post-operative management}

The patients were mobilised the following day with instructions to avoid extreme abduction of the thighs. Liquid diet was given in the first $48 \mathrm{~h}$. Soft diet was

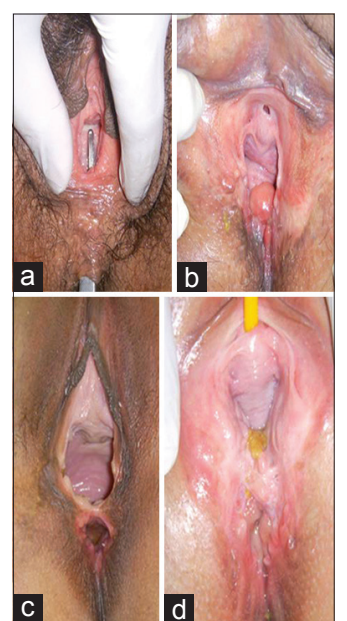

Figure 1: Clinical presentations. (a) Anorectal fistula, (b) complete tear, (c) gaping anus, (d) anal scar with faecal matter

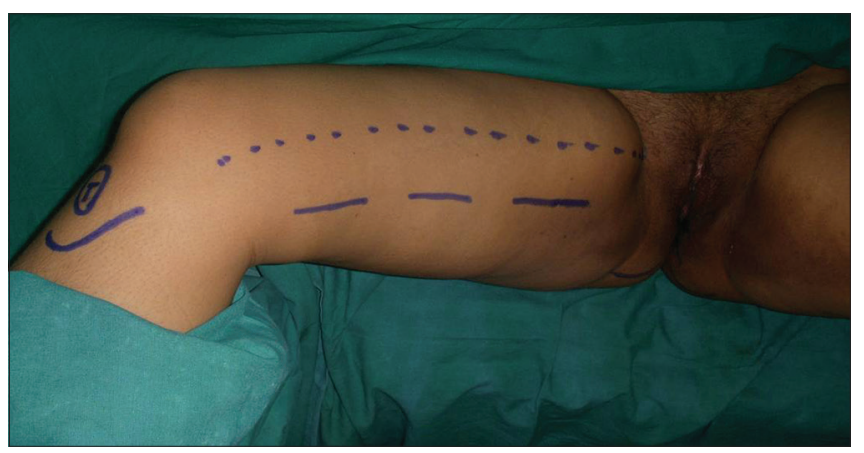

Figure 2: Markings

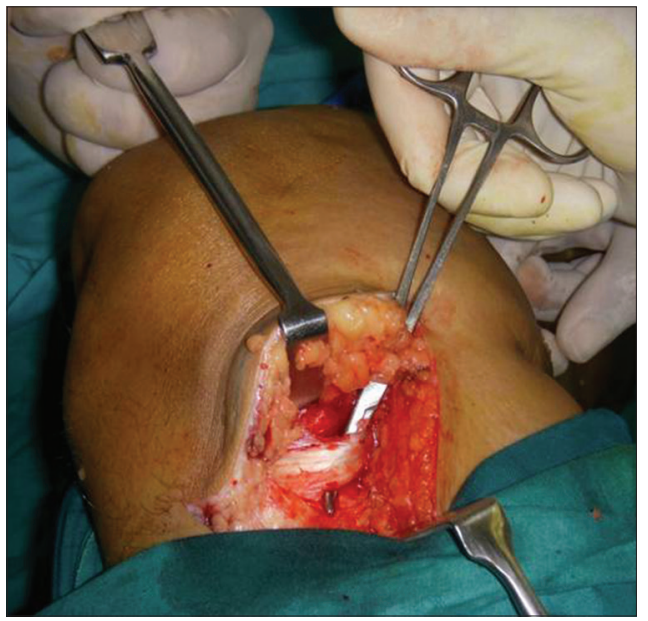

Figure 3: Harvest of gracilis with distal periosteum

advised for 5 days, regular diet thereafter. Stool softener was started from $5^{\text {th }}$ day and continued for 3 months.

From $5^{\text {th }}$ day onwards, the patients were instructed to do pelvic floor strengthening exercises and thigh adduction exercises 5 times every hour (anal sphincter contracted 
Table 4: Barium hold enema

\begin{tabular}{|c|c|c|c|c|}
\hline Case number & Barium hold pre-operative & Pre-operative hold time & Barium hold post-operative & Post-operative hold time \\
\hline 1 & Leak & Not able & Beaking appearance & $8 \min$ \\
\hline 2 & Leak & Not able & Not done & Not done \\
\hline 3 & Leak & Not able & Not done & Not done \\
\hline 4 & Rounded & $2 \min$ & Not done & Not done \\
\hline 5 & Leak & Not able & Not done & Not done \\
\hline 6 & Rounded appearance & $2 \min$ & Not done & Not done \\
\hline 7 & Rounded appearance & $3 \min$ & Beaking appearance & $10 \min$ \\
\hline 8 & Rounded appearance & $2 \min$ & Not done & Not done \\
\hline 9 & Rounded appearance & $2 \min$ & Not done & Not done \\
\hline 10 & Leak & Not able & Not done & Not done \\
\hline 11 & Leak & Not able & Not done & Not done \\
\hline 12 & Leak & Not able & Not done & Not done \\
\hline 13 & Leak & Not able & Beaking appearance & $5 \min$ \\
\hline 14 & Leak & Not done & Not done & Not done \\
\hline 15 & Leak & Not able & Not done & Not done \\
\hline 16 & Rounded appearance & $3 \min$ & Beaking appearance & $8 \mathrm{~min}$ \\
\hline 17 & Leak & Not able & Beaking appearance & $6 \min$ \\
\hline 18 & Leak & Not able & Beaking appearance & $12 \mathrm{~min}$ \\
\hline 19 & Leak & Not able & Beaking appearance & $8 \mathrm{~min}$ \\
\hline 20 & Rounded appearance & $2 \min$ & Beaking appearance & $10 \mathrm{~min}$ \\
\hline 21 & Leak & Not able & Not done & Not done \\
\hline 22 & Leak & Not able & Not done & Not done \\
\hline 23 & Rounded appearance & $2 \min$ & Beaking appearance & $8 \mathrm{~min}$ \\
\hline 24 & Leak & Not able & Beaking appearance & $10 \mathrm{~min}$ \\
\hline 25 & Leak & Not able & Not done & Not done \\
\hline 26 & Leak & Not able & Not done & Not done \\
\hline 27 & Leak & Not able & Not done & Not done \\
\hline 28 & Leak & Not able & Not done & Not done \\
\hline 29 & Leak & Not able & Not done & Not done \\
\hline 30 & Leak & Not able & Not done & Not done \\
\hline
\end{tabular}

Table 5: Manometry

\begin{tabular}{lcccc}
\hline $\begin{array}{l}\text { Case } \\
\text { number }\end{array}$ & $\begin{array}{c}\text { Pre- } \\
\text { operative } \\
\text { resting } \\
\text { presssure }\end{array}$ & $\begin{array}{c}\text { Post- } \\
\text { operative } \\
\text { resting } \\
\text { pressure }\end{array}$ & $\begin{array}{c}\text { Pre- } \\
\text { operative } \\
\text { squeeze } \\
\text { pressure }\end{array}$ & $\begin{array}{c}\text { Post- } \\
\text { operative } \\
\text { squeeze } \\
\text { pressure }\end{array}$ \\
\hline 24 & 49 & 70 & 65 & 100 \\
25 & 8 & 14 & 34 & 55 \\
26 & 21 & 50 & 23 & 120 \\
27 & 48 & 64 & 52 & 127 \\
28 & 24 & 40 & 32 & 61 \\
29 & 17 & 39 & 25 & 80 \\
\hline
\end{tabular}

for $10 \mathrm{~s}$, and subsequently thigh adducted for $10 \mathrm{~s}$ ). Confirmation regarding the proper execution of these exercises was carried out by rectal examination by the operating surgeon on the $7^{\text {th }}$ day. Intercourse was not advised for 3 months and squatting was not permitted for 3 months. No electrical stimulation of the muscle was done post-operatively.

Patients were followed up every week for a month, and once a month for 3 months. At each follow-up, patients

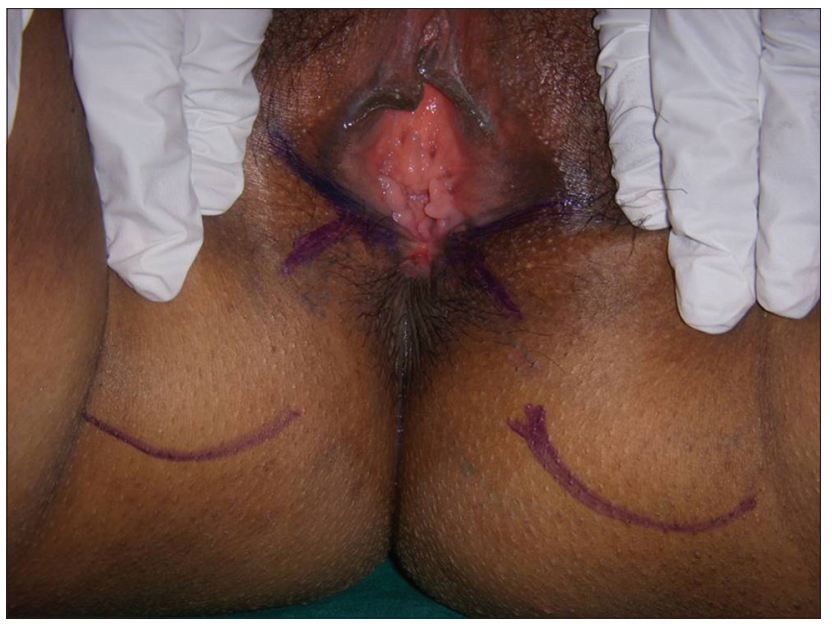

Figure 4: Perineal markings

were questioned about (i) faecal continence (ii) perineal/ vaginal soiling and (iii) ability to hold and duration. Per rectal examination was carried out as previously described. Barium hold enema and transperineal ultrasound were done at 3 months of follow-up. 


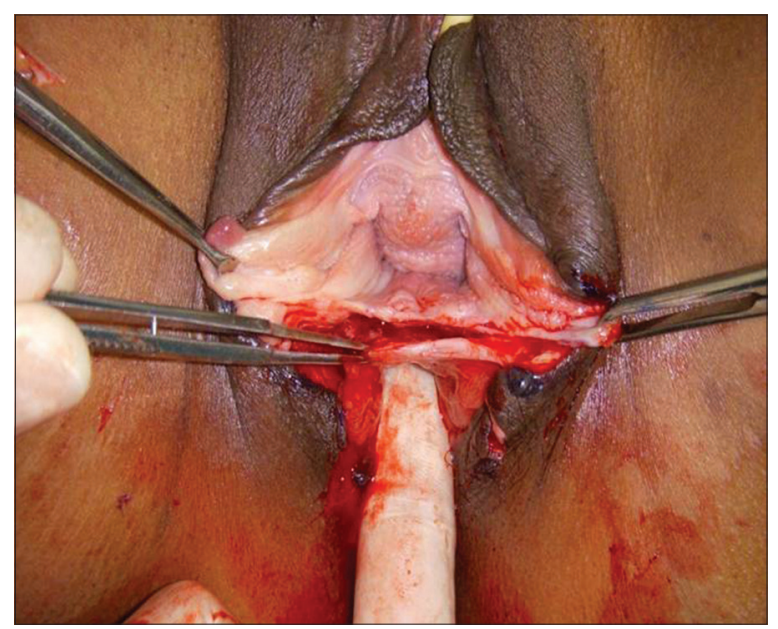

Figure 5: Dissection of anorectal and vaginal mucosa

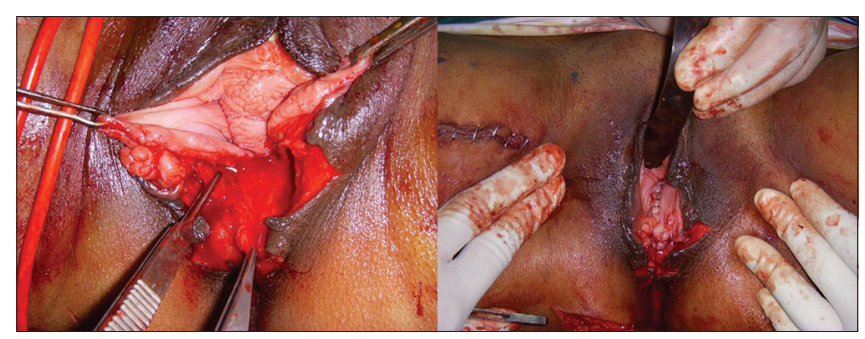

Figure 6: Trimming and repair of vaginal mucosa

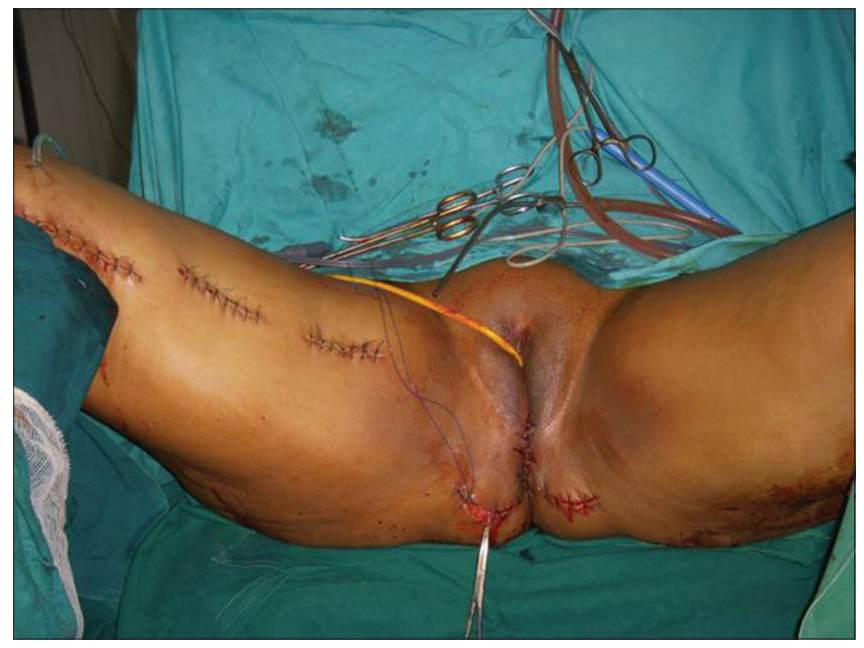

Figure 7: Tension adjustment

\section{RESULTS}

In this series 26 of the thirty patients had a satisfactory outcome and were a continent at an average follow-up of 8.8 months. The average age of the patients in the study was 36 years. Of the four patients who had unsatisfactory outcome average age was 39.7 years. The post-delivery duration in this series was ranging from 1.5 to 35 years with an average of 12.8 years.
In 26 patients, the pre-operative Park's score Grade IV improved to Grade I post-operatively. Two patients had Grade III and 2 patients Grade II Park's score post-operatively. Corman's score in 26 patients also improved from fair to excellent.

The DRE in 26 patients was noted to shift from lax and non-gripping to normal and gripping, at rest and squeeze, respectively. The distiguising finding on adduction of the thigh was very distinct constricting feel to the examining finger. We believe this was due to the contraction of the gracilis sling. It was noted that the feel to the examining finger at rest, squeeze and on adduction was weak in patients with a poor score.

The transperineal ultrasound, which measured thickness of external anal sphincter ranged from 1.3 to $3.2 \mathrm{~mm}$ (average $3.1 \mathrm{~mm}$ ) preoperatively. Post-operatively, it was done in 11 patients only due to socioeconomic reasons and the range was from 4 to $11 \mathrm{~mm}$ (average $10.1 \mathrm{~mm}$ ).

The barium enema hold demonstrated leak in the majority (22 patients) who could not hold at all. Remaining eight patients could hold the enaema for $2-3 \mathrm{~min}$. Post-operatively, it was done in ten patients only due to socioeconomic reasons and the holding time was notably improved between 5 and $12 \mathrm{~min}$.

Manometric studies showed significant improvement in both resting and squeeze pressures [Charts 1 and 2]. The preoperative resting pressure average was $27.83 \mathrm{~mm}$ of $\mathrm{Hg}$ which improved to $46.1 \mathrm{~mm}$ of $\mathrm{Hg}$ post-operatively. Furthermore, the pre-operative squeeze pressure average of $38.5 \mathrm{~mm}$ of $\mathrm{Hg}$ escalated to $90.5 \mathrm{~mm}$ of $\mathrm{Hg}$ post-operatively.

\section{Complications and unfavourable outcomes}

Scar hyperpigmentation was the commonest finding (26 patients) followed by scar hypertrophy (twenty patients). There was a tiny residual fistula in two patients with intermittent soiling. Gluteal wound infection was noted in three patients and thigh infection in two patients. One patient had deep vein thrombosis. Three patients complained of perineal pain after surgery [Table 6].

\section{DISCUSSION}

The results of gracilis muscle transposition for anal incontinence using Pickrell's original operation ${ }^{[1,2]}$ have 


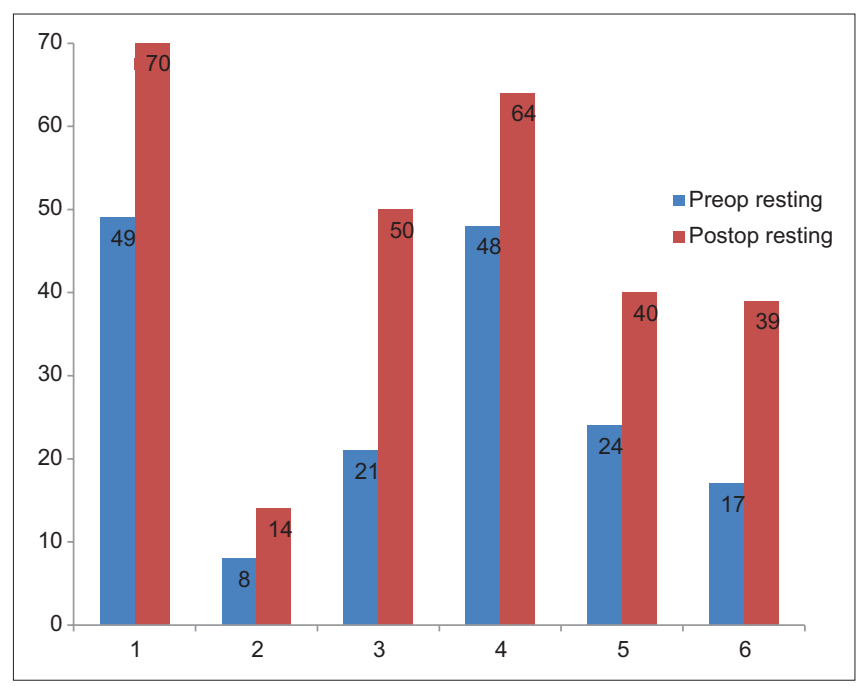

Chart 1: Resting pressure

Table 6: Complications

\begin{tabular}{lc}
\hline Complications & Number of patients \\
\hline Flap related complications & 0 \\
Thigh infection & 2 \\
Gluteal infection & 3 \\
Incontinence to flatus & 4 \\
Incontinence to liquids & 1 \\
Incontinence to stools & 0 \\
Residual fistula & 2 \\
Perineal pain & 3 \\
Deep vein thrombosis & 1 \\
Scar hypertrophy & 20 \\
Scar hyperpigmentation & 26 \\
\hline
\end{tabular}

been conflicting, and the mechanism of action of gracilis transposition in achieving continence is uncertain. The muscle does not seem to act as a dynamic sphincter but does offer passive resistance to outflow, and it has been suggested that the muscle acts as no more than an inert sling. ${ }^{[23,24]}$ Presentseriesdealswith cases oftherecto-vaginal fistula with incontinence wherein the gracilis has not only acted as a vascularised interpositional tissue between the repaired fistulae but also a distinct contracting ring being felt to the finger on DRE on adduction of the thigh. There can be difficulty in re-establishing the physiological length-tension relationship of the muscle and patients are reported as having to perform awkward movements to achieve continence. ${ }^{[23]}$ Contrary to this, it was noted in our series that none of the patients had to resort to any awkward position or movement to maintain continence or to defecate. Striated muscle is unable to maintain a contraction for a prolonged period ${ }^{[18]}$ and this problem has been addressed by implantation of a neuromuscular stimulator after gracilis transposition. ${ }^{[25,26]}$ The literature on gracilis reconstruction for faecal incontinence is

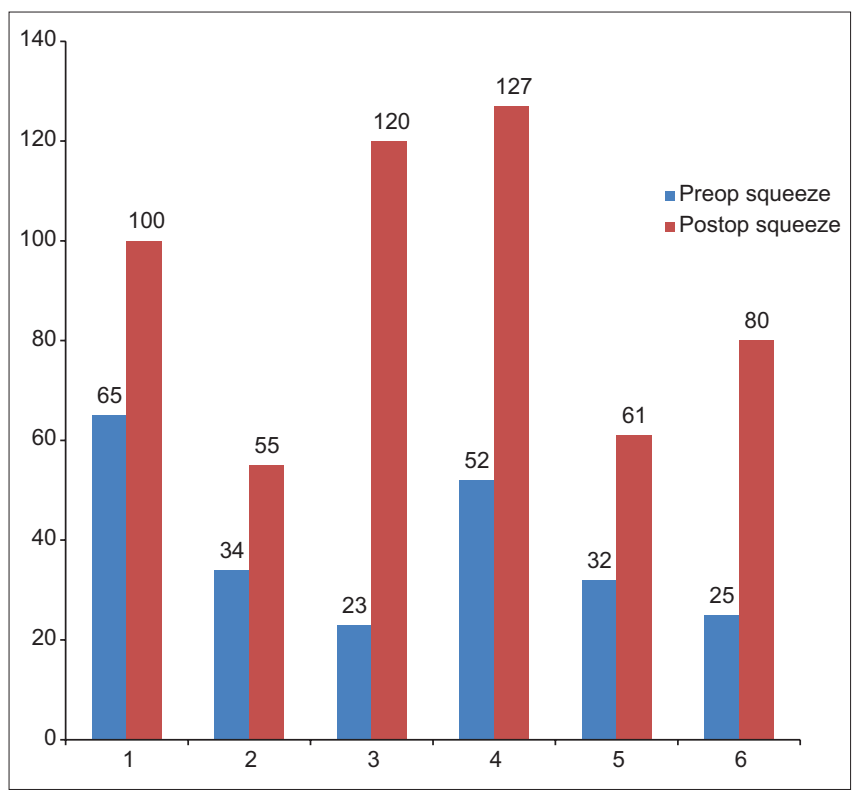

Chart 2: Squeeze pressure

dominated by the use of this technique in children, after trauma and after bowel surgery. In our series, we have not used stimulator for gracilis and all these cases are post-delivery recto-vaginal fistulae.

Discussion of post-obstetric cases of faecal incontinence in the literature remains small and mostly includes reports of sporadic cases in larger series of cases of faecal incontinence resulting from other causes. Despite an exhaustive search of the literature, we have managed to find ten cases recorded in which gracilis was used in the reconstruction. ${ }^{[8,11,18-20,27]}$ This study reports thirty women with post-obstetric faecal incontinence as a result of recto-vaginal tears who were treated with a single gracilis sling with a success rate of $86 \%$ (26 patients of thirty having a satisfactory outcome.) relieved entirely of faecal incontinence at all times. All the thirty patients had continence to solid stools. Further, of the four patients who had unsatisfactory outcome two patients had a considerable reduction of this problem with incontinence only to flatus. In this series, we noted that the interposed gracilis conferred adequate vascularised soft tissue interphase over the repaired fistula. The appropriate tension adjustment in adducted thigh by hitching the tendon to the ischial tuberosity gave a unique constricting feel on DRE, post-operatively. Rasmussen (2003) identified poorer results among patients older than 40-year-old when compared to those of younger patients. This study does not show this, as we had nine patients who were above forty of which only one had suboptimal outcome. 
The need for a defunctioning colostomy as a preliminary or concurrent step, with the treatment of anal incontinence surgically, is debated. Successful results without faecal diversion have been reported after direct repair, local procedures and gracilis transposition and most surgeons would now agree that a colostomy is not required for treatment of a straightforward anal sphincter injury. ${ }^{[28-32]}$ This study includes thirty reconstructions after obstetrical injury carried out successfully without colostomy, suggesting that this practice is not necessary.

Various objective methods of assessment of faecal continence have been used ${ }^{[11,20,23,33-39]}$ and reviewed. ${ }^{[20]}$ These include DRE, barium enema, anorectal manometry, endoanal ultrasound, electromyography, pudendal nerve terminal motor latency and defaecography and transit time of the colon. In this study, DRE, barium enaema and transperineal ultrasound have been used for assessment. Rectal manometry was done preoperatively and post-operatively in only a six cases, as it was previously unavailable. The manometric studies revealed the contraction of the gracilis as a distinct band. It was observed that the duration of squeeze pressures with gracilis contraction was twice that after only sphincter contraction.

The author feels that the use of gracilis in successfully treating these complex defects with an extreme degree of incontinence and psychological problems can be a boon to those faced with this problem.

\section{Financial support and sponsorship}

Nil.

\section{Conflicts of interest}

There are no conflicts of interest.

\section{REFERENCES}

1. Pickrell KL, Broadbent TR, Masters FW, Metzger JT. Construction of a rectal sphincter and restoration of anal continence by transplanting the gracilis muscle; a report of four cases in children. Ann Surg 1952;135:853-62.

2. Pickrell K, Masters F, Georgiade N, Horton C. Rectal sphincter reconstruction using gracilis muscle transplant. Plast Reconstr Surg 1954;13:46-55.

3. Corman ML. Management of fecal incontinence by gracilis muscle transposition. Dis Colon Rectum 1979;22:290-2.

4. Sultan $\mathrm{AH}$, Kamm MA, Hudson CN, Bartram Cl. Third degree obstetric anal sphincter tears: Risk factors and outcome of primary repair. BMJ 1994;308:887-91.

5. Sander P, Bjarnesen J, Mouritsen L, Fuglsang-Frederiksen A. Anal incontinence after obstetric third/fourth-degree laceration.
One-year follow-up after pelvic floor exercises. Int Urogynecol J Pelvic Floor Dysfunct 1999;10:177-81.

6. Bek KM, Laurberg S. Risks of anal incontinence from subsequent vaginal delivery after a complete obstetric anal sphincter tear. $\mathrm{Br}$ J Obstet Gynaecol 1992;99:724-6.

7. Sørensen M, Tetzschner $\mathrm{T}$, Rasmussen OO, Bjarnesen J, Christiansen J. Sphincter rupture in childbirth. $\mathrm{Br} \mathrm{J}$ Surg 1993;80:392-4.

8. Sultan $\mathrm{AH}$, Kamm MA, Hudson $\mathrm{CN}$, Thomas JM, Bartram $\mathrm{Cl}$. Anal-sphincter disruption during vaginal delivery. N Engl J Med 1993;329:1905-11.

9. Rieger N, Schloithe A, Saccone G, Wattchow D. A prospective study of anal sphincter injury due to childbirth. Scand J Gastroenterol 1998;33:950-5.

10. Fornell EU, Matthiesen L, Sjödahl R, Berg G. Obstetric anal sphincter injury ten years after: Subjective and objective long term effects. BJOG 2005;112:312-6.

11. Corman ML. Follow-up evaluation of gracilis muscle transposition for fecal incontinence. Dis Colon Rectum 1980;23:552-5.

12. Corman ML. Anal incontinence following obstetrical injury. Dis Colon Rectum 1985;28:86-9.

13. Corman ML. Gracilis muscle transposition for anal incontinence: Late results. Br J Surg 1985;72 Suppl:S21-2.

14. Leguit P Jr., van Baal JG, Brummelkamp WH. Gracilis muscle transposition in the treatment of fecal incontinence. Long-term follow-up and evaluation of anal pressure recordings. Dis Colon ssswRectum 1985;28:1-4.

15. Baeten CG, Bailey HR, Bakka A, Belliveau P, Berg E. Safety and efficacy of dynamic graciloplasty for fecal incontinence: report of a prospective, multicenter trial. Dynamic Graciloplasty Therapy Study Group. Dis Colon Rectum. 2000 J;43(6):743-51.

16. Fenner DE, Genberg B, Brahma P, Marek L, DeLancey JO. Fecal and urinary incontinence after vaginal delivery with anal sphincter disruption in an obstetrics unit in the United States. Am J Obstet Gynecol 2003;189:1543-9.

17. Rygh $A B$, Körner $H$. The overlap technique versus end-to-end approximation technique for primary repair of obstetric anal sphincter rupture: a randomized controlled study. Acta Obstet Gynecol Scand 2010;89:1256-62.

18. Christiansen J, Sørensen M, Rasmussen OO. Gracilis muscle transposition for faecal incontinence. Br J Surg 1990;77:1039-40.

19. George BD, Williams NS, Patel J, Swash M, Watkins ES. Physiological and histochemical adaptation of the electrically stimulated gracilis muscle to neoanal sphincter function. $\mathrm{Br} \mathrm{J}$ Surg 1993;80:1342-6.

20. Zmora O, Tulchinsky H, GurE, Goldman G, Klausner JM, Rabau M. Gracilis muscle transposition for fistulas between the rectum and urethra or vagina. Dis Colon Rectum 2006;49:1316-21.

21. Browning GG, Parks AG. Postanal repair for neuropathic faecal incontinence: Correlation of clinical result and anal canal pressures. Br J Surg 1983;70:101-4.

22. Hallan RI, Marzouk DE, Waldron DJ, Womack NR, Williams NS. Comparison of digital and manometric assessment of anal sphincter function. Br J Surg 1989;76:973-5.

23. Sangwan YP, Coller JA. Fecal incontinence. Surg Clin North Am 1994;74:1377-98.

24. Yoshioka K, Keighley MR. Clinical and manometric assessment of gracilis muscle transplant for fecal incontinence. Dis Colon Rectum 1988;31:767-9.

25. Cera SM, Wexner SD. Muscle transposition: Does it still have a role? Clin Colon Rectal Surg 2005;18:46-54.

26. Tillin $T$, Chambers M, Feldman R. Outcomes of electrically stimulated gracilis neosphincter surgery. Health Technol Assess 2005;9:1-102. 
27. Chapman AE, Geerdes B, Hewett P, Young J, Eyers T, Kiroff G, et al. Systematic review of dynamic graciloplasty in the treatment of faecal incontinence. Br J Surg 2002;89:138-53.

28. Corman ML. The management of anal incontinence. Surg Clin North Am 1983;63:177-92.

29. Fang DT, Nivatvongs S, Vermeulen FD, Herman FN, Goldberg SM, Rothenberger DA. Overlapping sphincteroplasty for acquired anal incontinence. Dis Colon Rectum 1984;27:720-2.

30. Pezim ME, Spencer RJ, Stanhope CR, Beart RW Jr., Ready RL, Ilstrup DM. Sphincter repair for fecal incontinence after obstetrical or iatrogenic injury. Dis Colon Rectum 1987;30:521-5.

31. Konsten J, Baeten CG, Spaans F, Havenith MG, Soeters PB. Follow-up of anal dynamic graciloplasty for fecal continence. World J Surg 1993;17:404-8.

32. Phillips RK, Brown T. Surgical management of anal incontinence part A. Secondary anal sphincter repair. In: Sultan, Thaker, Fenner, editors. Perineal and Anal Sphincter Trauma. London: Springer-Verlag; 2007. p. 144-53.

33. Swash M. Anorectal incontinence: Electrophysiological tests. $\mathrm{Br}$
J Surg 1985;72 Suppl: S14-5.

34. Schoetz DJ Jr. Operative therapy for anal incontinence. Surg Clin North Am 1985;65:35-46.

35. Goei R. Anorectal function in patients with defecation disorders and asymptomatic subjects: Evaluation with defecography. Radiology 1990;174:121-3.

36. Kaushal JN, Goldner F. Validation of the digital rectal examination as an estimate of anal sphincter squeeze pressure. Am J Gastroenterol 1991;86:886-7.

37. Han SJ, Park HJ, Kim CB, Hwang EH. Long-term follow-up of gracilis muscle transposition in children. Yonsei Med $\mathrm{J}$ 1995;36:372-7.

38. Bock JU, Jongen J. Diagnostic and therapeutic procedures in fecal incontinence in general practice of the surgically educated proctologist. Zentralbl Chir 1996;121:659-64.

39. Dobben AC, Terra MP, Deutekom M, Gerhards MF, Bijnen AB, Felt-Bersma RJ, et al. Anal inspection and digital rectal examination compared to anorectal physiology tests and endoanal ultrasonography in evaluating fecal incontinence. Int $J$ Colorectal Dis 2007;22:783-90.

\section{Author Help: Reference checking facility}

The manuscript system (www.journalonweb.com) allows the authors to check and verify the accuracy and style of references. The tool checks the references with PubMed as per a predefined style. Authors are encouraged to use this facility, before submitting articles to the journal.

- The style as well as bibliographic elements should be $100 \%$ accurate, to help get the references verified from the system. Even a single spelling error or addition of issue number/month of publication will lead to an error when verifying the reference.

- Example of a correct style

Sheahan P, O'leary G, Lee G, Fitzgibbon J. Cystic cervical metastases: Incidence and diagnosis using fine needle aspiration biopsy. Otolaryngol Head Neck Surg 2002;127:294-8.

- Only the references from journals indexed in PubMed will be checked.

- Enter each reference in new line, without a serial number.

- Add up to a maximum of 15 references at a time.

- If the reference is correct for its bibliographic elements and punctuations, it will be shown as CORRECT and a link to the correct article in PubMed will be given.

- If any of the bibliographic elements are missing, incorrect or extra (such as issue number), it will be shown as INCORRECT and link to possible articles in PubMed will be given. 